\title{
Charcot-Marie-Tooth Disease Type 4C
}

National Cancer Institute

\section{Source}

National Cancer Institute. Charcot-Marie-Tooth Disease Type 4C. NCI Thesaurus. Code C129864.

An autosomal recessive form of demyelinating Charcot-Marie-T ooth disease caused by mutations in the SH3TC2 gene, encoding SH3 domain and tetratricopeptide repeatcontaining protein 2 . 